\title{
Effects of Different Tuber Crop Flours and Melon Seed Meal on the Physicochemical and Sensory Properties of Biscuits
}

\author{
AGBARA Gervase Ikechukwu ${ }^{1 *} \&$ SULAIMAN Rainat Oyiza ${ }^{2}$ \\ ${ }^{1,2}$ Department of Food Science and Technology, University of Maiduguri, Nigeria. \\ ${ }^{*}$ Corresponding author's Email: giagbara@unimaid.edu.ng
}

Copyright: () 2021 Agbara Gervase Ikechukwu \& Sulaiman Rainat Oyiza. This is an open access article distributed under the terms of the Creative Commons Attribution License, which permits unrestricted use, distribution, and reproduction in any medium, provided the original author and source are credited.

Flours were made from cassava (C), white yam (Y), Irish potato (I), sweet potato (S), they were used to replace $25 \%$ of wheat flour, the resulting blends were fortified with either fullfat(F) or defatted(D) melon seed meal (MSM), the blends with constant blend ratio (65:25:10) were coded as follows: WCF, WCD, WIF, WID, WYF, WYD, WSF, WSD and the experimental control was commercial wheat flour (W100:0:0). Biscuits were made with the blends. Standard procedures were used to evaluate the particle size distribution of the flours, proximate composition of the blends and the biscuits as well as the physical and sensory properties of the biscuits. Results revealed that wheat and cassava flours had finer granulation as indicated by the least retention on $<0.25 \mathrm{~mm}$ sieves contrary to higher percent retentions for yam, sweet and Irish potato on the same sieves $(<0.250 \mathrm{~mm})$. But on higher sieves $(>0.50 \mathrm{~mm})$, all the flours had minimal retentions except cassava flour $(42 \%)$. Significant observation was the enhancement of the nutritive value of the blends and biscuits. Moisture, crude protein, crude fat, crude fibre, total ash and carbohydrate contents of the blends varied significantly $(\mathrm{p}<0.05): 7.70-10.61 \%, 5.25-12.40 \%, 1.92-15.15 \%, 2.87-5.71 \%, 1.02-3.29 \%$ and $59.58-72.43 \%$ respectively, and for the various biscuits, the variations were $3.84-4.80 \%, 6.12-8.74 \%, 5.27-16.88 \%, 1.61-2.98 \%, 2.19-6.52 \%$ and $62.76-75.80 \%$ for moisture, protein, fat ash, fibre and carbohydrate respectively. The spread ratio (7.9-9.6) of the modified biscuits were slightly higher especially those with fullfat MSM also wheat biscuits were harder than the treated. Sensory attributes of the treated biscuits with the exception of $25 \%$ Irish potato biscuits, competed favorably with wheat biscuits on all sensory attributes investigated, although wheat biscuits outscored the modified biscuits on all the attributes Therefore, it was concluded that nutritive biscuits could be successfully prepared from flour blends containing wheat , tuber crop and MSM (fullfat or defatted) without undermining sensory properties associated with conventional biscuits.

Keywords: Biscuits, Tuber crops, Melon seeds, Defatting, Flour particles.

\section{Introduction}

Biscuits are low moisture, flat crispy cakes usually produced from chemically leavened and baked wheat dough. Like many other wheat-based goods, biscuits are the foremost snack that drives modern civilization, a phenomenon associated with sprouting of new urban centers, heightened crave for refined cereals, convenient foods, eat-aways and city ward migration [1]. Biscuits come in different sizes, shapes, and composition and mostly produced from refined soft wheat flour. Biscuits are noted for high sugar, high fat and low dietary fibre contents [2-3], therefore contemporary biscuits in the markets are energy-dense highly flavoured foods which are consumed by all classes of people, the tendency to over consume is high and therefore the incidence of malnutrition is also high among the children, adolescents and youths who are the main biscuits consumers.

Rajana et al. [4] reported high prevalence (84\%) of snacking among teens, urban residents of both middle and high income groups in Mauritius. Biscuits is the commonest item in children school food box in Nigeria, for many mothers, it is the first unrecognized weaning food. Soft wheat flour generally used for biscuits making are of low protein quality and quantity, however better than those of tuber crops. Wheat refining through milling and sieving reduces considerably useful chemical constituents [5], therefore reliance on wheat biscuits for adequate supply of protein and micronutrients is not feasible, such consumers are deprived of the essential nutrients needed for healthy living, this deficiency is responsible for high incidence of diet related disorders [6]. According to Chandra et al. [7], multi-grain blends provide higher level of micro and macro nutrients than single grain flour. Composite flour 
according to Edema et al. [8] and Giami et al. [9] offer many benefits including increased utilization of local food crops, reduction of dependence on imported wheat and increased production of cheap and nutritionally enhanced food products. Unlike wheat, a cold weather crop, roots and tubers are abundantly grown in Nigeria, a tropical country with diverse agro-climatological zones that accommodates the cultivation of tubers such as cassava, yam, sweet and Irish potatoes. Nigeria is a leading producer of Yam [10] and Cassava [11] in the world, and a major producer of sweet potato in SubSaraharan Africa. Substantial cultivation of Irish potatoes occurs in high altitude places in Nigeria such as Jos and Mambila plateaux and through irrigation farming in some parts of the Northern Nigeria. Roots and tubers are characterized by high moisture content (60-90\%), starchy with poor protein quality and quantity, a protein generally inferior to those of grain legumes.

High moisture contents and bulkiness place constraints on their storage, packaging and distribution, therefore susceptiblity to post-harvest losses is high, which are incurred in the efforts to bring them to urban centers where they command higher price and greater demand. It's commonly believed that tuber crops are the main supplier of calorie to resource poor families mostly farmers in those regions of the world where malnutrition is endemic [12].

According to Chandrasekara and Kumar [13], root and stem tubers offer nutritional and health benefits such as anti-oxidative, hypoglycemic, hypocholesterolemic, antimicrobial and immunidilatory activities through the presence of bio-active compounds such as phenolics, vitamin C, saponins, etc. Drying has continued to be the foremost food preservative technique in Nigeria, the tropical climate positioned sun drying as a veritable tool to reduce postharvest losses, a factor that negatively impact on food availability, accessibility and affordability. This can further be extended to artificial drying which is capable of producing high quality flours from roots and tubers with which composite flours can be formulated with wheat flour for the production of value added baked goods. Wheat flour is an extraction of wheat endosperm containing unique proteins that combine with water to form gluten during dough formation, the gluten is responsible for the visco-elastic nature of wheat dough and the ability to retain leavening gases during fermentation and baking [14].

Sulphur amino acids which are deficient in the proteins of most tuber crops [13], the same amino acids are augmented by their availability in wheat flour protein as in most cereals. Blending of both yields a composite flour with a better protein quality. However, provision of protein-enriched baked items such as biscuits requires the inclusion of legume seed meal from oil seeds such as citrullus colocynthis locally called egusi, a member of several species of curcubitaceae generally called melon. This crop grows well in Nigeria, the paste of the shelled seed is a common soup thickener and when fermented a soup condiment called ogiri is obtained which is used extensively by many tribes of Southern Nigeria [15]. Citrullus colocynthis seeds are a good source of high quality protein, micro-nutrients and beneficial phytochemicals [16-17]. Studies involving the use of seed meal from the members of curcubitaceae family to fortify food products abound in the literature, only recently Das et al. [18] enhanced the nutritive value of cookies using pumpkin seed meal apart from a similar work by Saraswathi et al. [19].

It has been noted that prolonged denial of calorie and nitrogen substrates are the root cause of protein energy malnutrition, still endemic in cassava belt of the world. Therefore, the present study evaluated the physicochemical and sensory properties of biscuits produced from flour blends of wheat, tuber crops and melon seed. 


\section{Materials and Methods}

\subsection{Materials}

Fresh cassava, Irish potatoes, sweet potatoes and yam tubers were purchased from Gamboru market, Maiduguri northeast Nigeria. Other items obtained were shelled seeds of Citrillus Colocynthis (egusi), wheat flour (Golden Penny Flour Mills Nigeria), baking fat (Simas, Indonesia), granulated sugar (Dangote Plc, Lagos), other ingredients such as powdered milk, eggs, baking powder etc were purchased from local stores. Chemicals/reagents were obtained from the Department and were of analytical grade.

\subsection{Preparation of the raw materials}

The tubers were washed, peeled with a stainless knife, sliced into thin slabs ( $<5 \mathrm{~mm}$ thickness), separately placed into bowls containing hot water $\left(\sim 90^{\circ} \mathrm{C}\right)$ and allowed to stand for $5 \mathrm{~min}$, after each portion was then rinsed with tap water and then spread on a perforated tray and placed in a solar tent dryer $\left(45-50^{\circ} \mathrm{C}\right)$ until sufficiently dried $(2-3$ days). Dried slices were ground separately in a laboratory hammer mill unsieved for sieve analysis and sieved

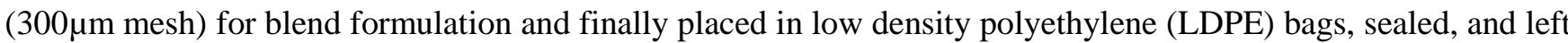
at room temperature until needed.

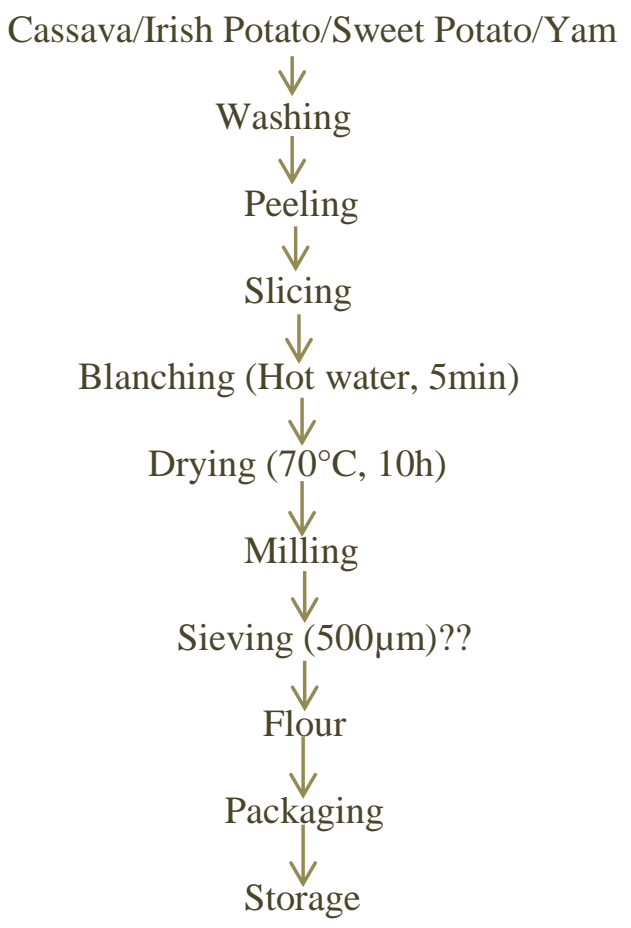

Fig.1. Flowchart for the production of flour from Cassava,

Irish and Sweet Potatoes and Yam

\subsection{Preparation of the Melon Seed Meal (MSM)}

Shelled seeds were sorted, washed and placed in a cabinet dryer $\left(50^{\bullet} \mathrm{C}\right)$ until sufficiently dried, The dried seeds were ground, portioned into two, one portion was defatted by infusing into a bowl containing aquous ethanol $80 \% \mathrm{~V} / \mathrm{V}(1: 3)$ mixed thoroughly, the solvent drained and the residue wrapped in a cheese cloth and squeezed strongly, then declumped and oven dried $\left(70^{\bullet} \mathrm{C}, 5 \mathrm{~h}\right)$. The defatted MSM was further pulverized in a kitchen mixer. 


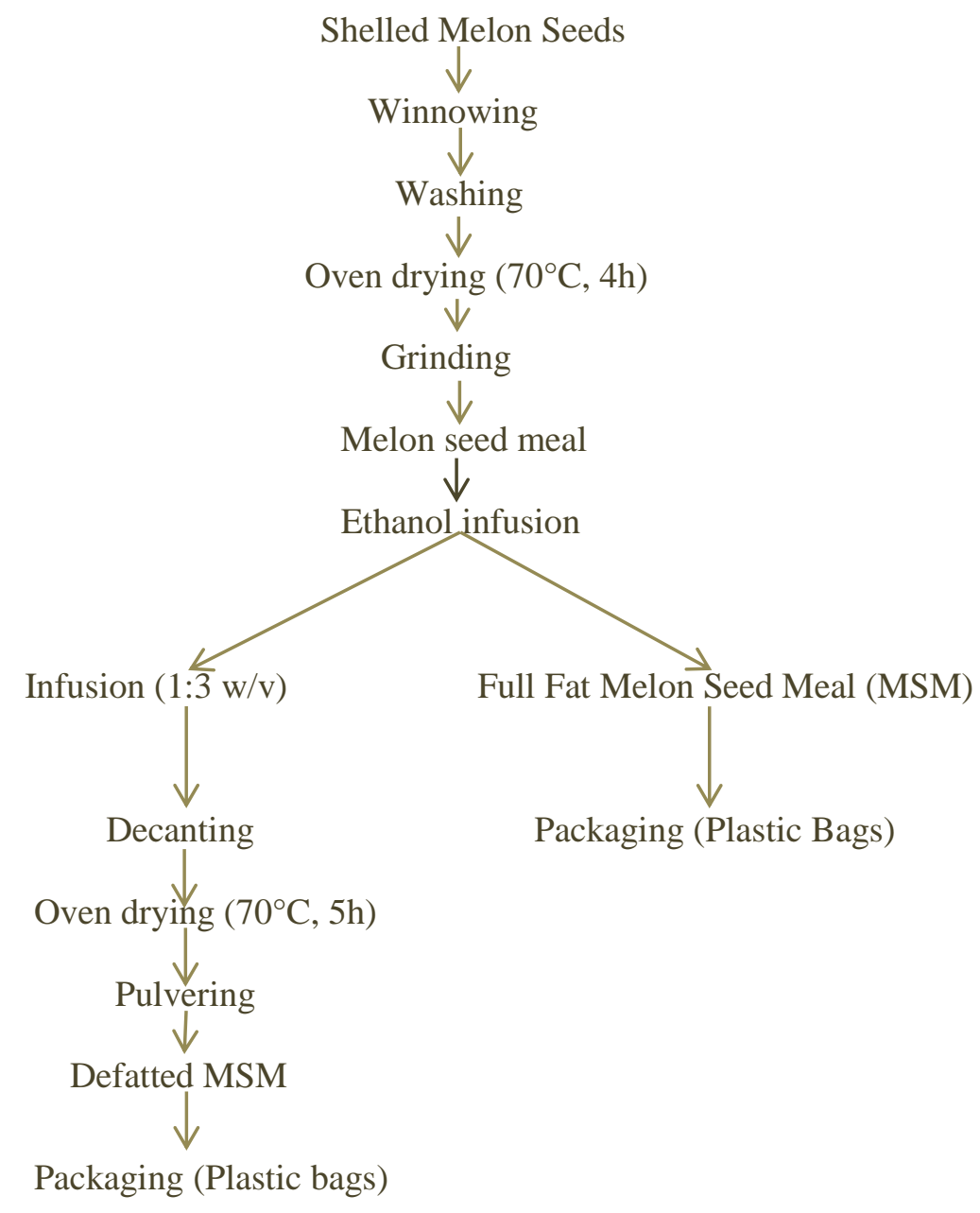

Fig.2. Flowchart for the production of full fat and defatted melon seed meal

\subsection{Formulation of the flour blends}

Melon seed meal (MSM), full fat (F), defatted (D) and flours from the tubers: cassava (C), Irish Potato (I), yam (Y) and sweet potato $(\mathrm{S})$ were mixed with wheat flour $(\mathrm{W})$ in the ratio of $65 \%(\mathrm{~W}), 25 \%$ tuber flour and $10 \%$ melon seed meal (MSM), defatted(D) and fullfat (F). The codes for the formulations were : (i) WCF(ii) WCD(iii) WIF (iv) WID(v) WYF(vi) WYD (vii) WSF (viii) WSD all in the ratio of 62:25:10. And the control was 100\% wheat flour (W100:0 :0). Each blend was placed in a Kenwood Mixer and mixed for 2 min, medium speed.

\subsection{Biscuit Production}

The recipe used for the biscuit production was a modification of Chandra et al. [7]. On 100g flour basis, 30g cooking fat, $30 \mathrm{~g}$ sugar, $1.5 \mathrm{~g}$ common salt, $1.5 \mathrm{~g}$ baking powder and $50-60 \mathrm{ml}$ water (Table $1 \& 2$ ).

The fat and sugar were creamed until a uniformed fluffy mass was obtained, other ingredients were added including water and mixed in a Kenwood Mixer at 10min medium speed, the resulting dough was placed on a greased board and rolled with a rolling stick until a thin uniform dough sheet of less than 5mm thickness was obtained and cut with biscuit cutter of diameter $5 \mathrm{~mm}$. The cut dough pieces were placed on a greased tray and placed in a preheated oven and baked at $180^{\circ} \mathrm{C}, 15 \mathrm{mins}$. The baked biscuits were left to cool to room temperature and later stored in separate transparent containers until needed for analysis. 
Table 1. Composite flours and the bend ratios

\begin{tabular}{|c|c|c|c|c|c|c|}
\hline Formulations & W(g) & C(g) & Y(g) & S(g) & F(g) & D(g) \\
\hline WCF & 65 & 25 & - & - & 10 & - \\
\hline WIF & 65 & 25 & - & - & 10 & - \\
\hline WYF & 65 & - & 25 & - & 10 & - \\
\hline WSF & 65 & - & 25 & - & 10 & - \\
\hline WCD & 65 & - & - & - & - & 10 \\
\hline WID & 65 & - & - & 25 & - & 10 \\
\hline WYD & 65 & - & - & 25 & - & 10 \\
\hline WSD & 65 & - & - & - & - & 10 \\
\hline W & 100 & - & - & - & - & - \\
\hline
\end{tabular}

Wheat (W), Irish Potato (I), Cassava (C), Yam (Y), Sweet Potato (S), Full fat (F) and

Defatted (D) Melon Seed Meal.

Table 2. Recipe showing the quantity of each ingredient used for biscuits preparation

\begin{tabular}{|c|c|}
\hline Ingredients & Quantity \\
\hline Wheat flour (g) & 65 \\
\hline Non-wheat flours (g) & 25 \\
\hline Melon Seed Meal (g) & 10 \\
\hline Granulated Sugar (g) & 30 \\
\hline Baking Powder (g & 1.5 \\
\hline Margarine (g) & 30 \\
\hline Egg (Medium size) & 1.0 \\
\hline Salt (g) & 0.5 \\
\hline Milk powder (g) & 5 \\
\hline Water (ml) & $50-65$ \\
\hline
\end{tabular}




\subsection{Physiochemical Analysis}

\subsubsection{Particle size distribution analysis}

Test sieves (Endecott's, UK) were stacked in decreasing order of screen size and the receiver pan was the last. Fifty gram $(50 \mathrm{~g})$ each of cassava, Irish, and sweet potato and yam flours was placed on the topmost sieve; the sample was sieved for 10min using an Endecott sieve shaker.The amount left on each sieve, converted to percent was regarded as the dominant particle size for that flour on that sieve AACC [20]. The $\%$ retentions were used to classify the flours into coarse, medium or fine.

\subsubsection{Proximate composition of the blends and the biscuits}

The moisture, crude protein (NX6.25), crude fat, total ash, crude fiber, of the flour blends and the biscuits were determined using the procedures of AACC [20] and carbohydrate contents were obtained by 'difference'.

\subsubsection{Dimension and spread ratio (SR) of the biscuits}

Six biscuits were arranged edge to edge horizontally, the length was taken and the value obtained was divided by six to obtain the average diameter (D) of the biscuits, the same biscuits were stacked vertically and the height was measured and divided by six to obtain the average thickness $(\mathrm{T})$ of the biscuits, with these values the spread ratios (D/T) were calculated, AACC [20].

\subsubsection{The hardness of the biscuits}

The method of Okaka and Isehi [21] was used to determine the strength of the biscuits. A biscuit was paced centrally between two parallel bars (30mm apart). Weights were placed on the biscuits; the total weight that caused the snapping/breaking of the biscuit was taken as the breaking strength in grams. Hardness was also tested using hardness tester. (TBH-30, Eureka, GmbH and the results expressed in Newton (N)).

\subsubsection{Sensory evaluation of the biscuits}

Twenty (20) member semi-trained panel drawn from the staff and students of Food Science and Technology, University of Maiduguri were used to evaluate the sensory attributes (taste, color, flavour, taste, crispness, texture and acceptability) of the biscuits on the basis of 9-point Hedonic scale where one (1) represents extremely disliked and nine (9) extremely liked and five (5) represents neither like nor dislike.

Samples of the biscuits were randomly presented to the panelists and warm water was provided for mouth gargling.

\section{Results and Discussion}

\subsection{Particle size distribution of the various flours for blends formulation}

Expectedly, wheat flour recorded the least retention $(18.01 \%)$ on $<0.25 \mathrm{~mm}$ sieves therefore had the finest granulation, not far different from cassava flour (20.67\%). Oladunmoye et al. [22] observed that among four flours, wheat flour had the least particle size, next was cassava flour, then maize flour and lastly cowpea flour with the biggest flour particles. A composite flour with particle size less than $0.18 \mathrm{~mm}$ is needed for a bread with good texture and volume [22]. Roller mills used in industrial wheat milling through series of reductions and siftings 
produce finer flour than products of attrition mills used for flour production as in this study. Irish potato and yam had equivalent granulations and the coarsest respectively $60.05 \%$ and $58.70 \%$ retentions on $<0.25 \mathrm{~mm}$ sieves. Finer flour particles is associated with greater cell rupture and release of cell components. According to Marchini et al. [23] and Bouire et al. [24], extensive milling is associated with greater starch damage, lower water absorption, higher peak and final viscosities of flour. On $0.5 \mathrm{~mm}-0.25 \mathrm{~mm}$ class of sieves, $60.34 \%$ and $50.3 \%$ retentions were recorded for wheat and sweet potato flours respectively which indicated the presence of greater number of bigger flour particles, other flours (yam, cassava and Irish potato) had more or less equivalent granulation on $0.5 \mathrm{~mm}-0.25 \mathrm{~mm}$ sieves. But on $>0.5 \mathrm{~mm}$ sieves, Yam, sweet potato and Irish potato flours had the least retentions recorded respectively $6.5 \%, 5.42 \%$ and $11.38 \%$ and cassava flour the highest retention $(42.04 \%)$, therefore the coarsest on $>0.5 \mathrm{~mm}$ sieves while wheat flour came a distant second $(21.64 \%)$. This goes to show that grinding produces flour with different particle sizes even in the same flour. Flour particle size distribution has impact on the textural characteristics of the end-products, as well as the chemical composition and functional properties of the blends. Belorio et al. [25] reported decreased water holding capacity, swelling volume and elastic modulus of dough from flour with higher flour particle size as well as increased diameter and spread ratio of the cookies and decreased cookie hardness. Several studies reported an alterations in flour particle size distribution and dough rheology on blending of legume flour with wheat flour. Gadzama and Agbara [41] similarly reported for blends formulated from sorghum or pearl millet flours with legume flours. Mohammed et al. [26] reported increased water absorption and dough development time and reduced dough extensibility and resistance to deformation on addition of chickpea to wheat flour.

Table 3. Particle size distribution expressed as \%retention of the various flours used for the blend formulations

\begin{tabular}{|c|c|c|c|}
\hline Flours & $\begin{array}{c}\text { Fine particles } \\
(<\mathbf{0 . 2 5 0} \mathbf{m m})\end{array}$ & $\begin{array}{c}\text { Intermediate particles } \\
(>\mathbf{0 . 2 5 0 - 0 . 5 0 m m})\end{array}$ & $\begin{array}{c}\text { Coarse particles } \\
(>\mathbf{0 . 5 0 m m})\end{array}$ \\
\hline Wheat & $18.01 \mathrm{~d}$ & $60.34 \mathrm{a}$ & $21.64 \mathrm{~b}$ \\
\hline Cassava & $20.67 \mathrm{c}$ & $36.10 \mathrm{c}$ & $42.04 \mathrm{a}$ \\
\hline Yam & $58.70 \mathrm{a}$ & $32.72 \mathrm{~d}$ & $6.95 \mathrm{~d}$ \\
\hline Sweet potato & $37.84 \mathrm{~b}$ & $50.3 \mathrm{~b}$ & $11.38 \mathrm{c}$ \\
\hline Irish potato & $60.05 \mathrm{a}$ & $34.38 \mathrm{c}$ & $5.42 \mathrm{~d}$ \\
\hline
\end{tabular}

\section{Proximate composition of the flour blends and wheat flour}

The moisture, ash, crude protein, crude fat, crude fibre and the carbohydrate contents of the blends varied significantly $(\mathrm{p}<0.05)$ from $7.70-10.61 \%, 1.02-3.29 \%, 5.25-12.40 \%, 1.92 \%-15.15 \%, 2.87 \%-5.71 \%$ and 59.58-72.43\% respectively. Ash, crude fibre, crude fat, of the blends were enhanced when Obasi et al. [27] partially substituted wheat flour with raw or roasted African yam bean. Moisture contents of the blends were generally low, an indication of high dry matter content and potential storage stability provided appropriate packaging and storage conditions are provided. However, wheat flour moisture was higher (10.61\%) followed by WIF (10.04\%), WSF(10.01\%); moisture levels were lower in the treated, slightly higher in the formulations containing full fat 
MSM. Equilibrium moisture content of biological materials reflect the relative humidity of the surrounding environment, their hygroscopicity and particle size distribution in case of flours. Chandra et al. [7] similarly observed decrease in moisture as wheat flour was partially substituted. For commercial refined flours, ash is an indicator of the degree of extraction and colour index of the flour, here commercial wheat flour (Nigeria Flour Mills, Lagos) had the least and increased in the blends as lower ash wheat flour was partially replaced by higher ash starchy tuber flours and MSM, consequently the flour blends had greater ash, crude fiber and carbohydrate contents, even at that it was observed that blends containing full fat had greater ash contents, the highest were WCF (3.29\%), WYF (3.11\%) and WSD (3.06\%). Saini et al. [28] and Klunklin and Savage [29] reported greater ash and fibre contents in the formulations than in wheat flour for biscuit preparation. The higher protein of the wheat flour $(12.40 \%)$ revealed that its substitution with low protein tuber flours led to reduction of its protein level which in turn reduced the gluten content critical for baked products preparation, therefore the blends had lower protein contents and 10\% MSM inclusion in the formulations contributed slightly to the level of protein, as most tuber flours are known to contain less than 5\% protein (dwb); formulations containing full fat MSM had slightly greater level of protein than blends with defatted MSM, the same scenario was also repeated in the fat contents of the blends (8.83-15.15\%), for obvious reason, the effect of dafatting with aqueous ethanol (80\% V/V). Avoidance of fat rancidification is a point to consider in the packaging and storage of blends with enhanced fat contents. Wheat flour is not known as a rich source of fat, moreover milling process further reduces the level, as observed in commercial wheat flours. A value of $1.92 \%$ was recorded for wheat flour used in this study. Wheat flour and the blends containing defatted MSM had greater carbohydrate contents which significantly varied from 59.58\% (WSF), $59.88 \%$ (WIF), $60.52 \%$ (WCF) to $72.43 \%$ (W100:00) signifying that the the treated blends contained more of other nutrients than the control.

Table 4. Proximate composition (\%) of the wheat-tuber-melon seed meal blends (65:15:10) for biscuit production

\begin{tabular}{|c|c|c|c|c|c|c|}
\hline Formulations & Moisture & Ash & $\begin{array}{c}\text { Crude } \\
\text { Protein }\end{array}$ & Crude Fat & $\begin{array}{c}\text { Crude } \\
\text { Fiber }\end{array}$ & Carbohydrate \\
\hline W100:00 & $10.61^{\mathrm{a}}$ & $1.02^{\mathrm{d}}$ & $12.4^{\mathrm{a}}$ & $1.92^{\mathrm{f}}$ & $2.87^{\mathrm{d}}$ & $72.43^{\mathrm{a}}$ \\
\hline WCF & $9.33^{\mathrm{bc}}$ & $3.29^{\mathrm{a}}$ & $7.87^{\mathrm{c}}$ & $15.08^{\mathrm{ab}}$ & $4.98^{\mathrm{b}}$ & $60.52^{\mathrm{c}}$ \\
\hline WCD & $7.70^{\mathrm{b}}$ & $2.81^{\mathrm{b}}$ & $6.82^{\mathrm{d}}$ & $10.49^{\mathrm{c}}$ & $4.05^{\mathrm{bc}}$ & $66.12^{\mathrm{b}}$ \\
\hline WIF & $10.04^{\mathrm{ab}}$ & $2.60^{\mathrm{c}}$ & $7.70^{\mathrm{c}}$ & $10.71^{\mathrm{c}}$ & $3.18^{\mathrm{c}}$ & $59.88^{\mathrm{c}}$ \\
\hline WID & $9.88^{\mathrm{b}}$ & $2.54^{\mathrm{c}}$ & $6.70^{\mathrm{d}}$ & $9.22^{\mathrm{de}}$ & $3.25^{\mathrm{c}}$ & $71.96^{\mathrm{a}}$ \\
\hline WYF & $9.82^{\mathrm{b}}$ & $3.11^{\mathrm{ab}}$ & $5.60^{\mathrm{e}}$ & $15.15^{\mathrm{a}}$ & $2.96^{\mathrm{d}}$ & $63.51^{\mathrm{bc}}$ \\
\hline WYD & $9.80^{\mathrm{b}}$ & $2.93^{\mathrm{b}}$ & $5.25^{\mathrm{ef}}$ & $9.96^{\mathrm{d}}$ & $4.28^{\mathrm{bc}}$ & $71.24^{\mathrm{a}}$ \\
\hline WSF & $10.01^{\mathrm{ab}}$ & $2.87^{\mathrm{b}}$ & $8.24^{\mathrm{b}}$ & $10.06^{\mathrm{cd}}$ & $5.71^{\mathrm{a}}$ & $59.58^{\mathrm{c}}$ \\
\hline WSD & $9.75^{\mathrm{b}}$ & $3.06^{\mathrm{ab}}$ & $8.11^{\mathrm{b}}$ & $8.83^{\mathrm{e}}$ & $5.04^{\mathrm{ab}}$ & $66.91^{\mathrm{b}}$ \\
\hline
\end{tabular}

Results reported as mean of duplicate determinations, means within a column with similar superscripts are significantly not different ( $p>0.05)$. W=wheat (65\%), C= cassava (25\%), I=Irish potato (25\%), $S=$ sweet potato (25\%), Y=Yam (25\%), F=Full fat melon seed meal (10\%), D=Defatted melon seed meal (10\%). 


\section{Proximate composition of the various wheat-tuber-melon seed meal biscuits}

Moisture contents of the various biscuits were generally low (3.80-4.70\%), usually influenced by biscuit formulation and baking conditions and the values re-choes well known fact that biscuits are low moisture flat cakes [3]. Observed variations in the moisture level of the biscuits were not significantly different ( $p>0.05)$, coinciding with the moisture contents of malted barley-bran biscuits reported by Ikuomola et al. [30]. Multigrain biscuits moisture reported by Kumar et al. [30], Agu and Okoli [31] beniseed biscuits (5.60-10.43\%) had higher moisture values as well as the moisture levels reported by Okoye and $\mathrm{Ob}$ [32] for wheat African yam bean biscuits. The variations can only be attributed to differences in biscuit formulation and baking conditions. The low moisture contents of the biscuits implied that they were very hygroscopic after exiting the oven, therefore such biscuits require packaging material with high moisture barrier capacity to avoid moisture absorption and subsequent reduction of sensory properties and deterioration. Protein contents of the various biscuits varied from $6.12 \%$ in W100:00 to 8.66\% in (WSD). Treated biscuits had slightly enhanced protein contents compared with $6.12 \%$ for wheat biscuit. Among the treated, no clear cut difference in protein contents was observed, whether full fat or defatted MSM treated.This is because blending ratio was constant for all the formulations.

Melon seeds like other oil seeds contain high level of protein $[33,18]$, especially the defatted meal, the differences in the protein contents of the treated biscuits is attributable to the slight differences in the protein contents of the various tuber flours, in this case sweet potato flour had greater level of protein which manifested in enhanced protein contents of the blends and biscuits containing sweet potato, although among tuber flours yam and potato flours are known to contain higher protein than others. Dadson et al. [34] did not witness any reduction in fat and protein of the wheat-yam biscuits with reference to wheat biscuit indicating protein enhancing effect of MSM. It was observed that defatted MSM with aqueous ethanol led to slight decrease in the protein and ash contents of the meal. Comparable protein contents were reported by Apoteola and Fashakin [35] for wheat-cocoyam-soybean biscuits, and multigrain biscuits reported by Kumar et al. [30]; higher protein contents were reported by Elizabeth and Abiodu [36] for wheat-cassava-soy malt biscuits and Saraswathi et al. [19] for wheat-pumpkin-flaxseed biscuits. Most biscuits are produced from low protein soft wheat of high extraction, consequently the wheat biscuits had the least protein content which 10\% MSM fortification only slightly enhanced as observed in the treated biscuits. Most tuber crop flours contain even lower amount of protein than soft wheat flours. Fat content of biscuit formulations is usually higher compared with the amounts used in bread making; reported amounts in the various recipes vary from formulation to formulation but in this study, the amount used was 30\% fat flour basis, and $10 \%$ inclusion of full fat MSM was too small to greatly enhanced the fat contents of the biscuits which varied from $16.0 \%$ in WSF, $15.00 \%$ in WCF to 5.27\% WYD, 6.59\% WID. For obvious reasons, the biscuit with tuber flours and defatted MSM contained the least. Dietary fiber represents the soluble and insoluble material needed for bowel health, slow glucose release and for general well-being of humans. Use of refined wheat flour for biscuits making yields biscuits with low dietary fiber, however substitution of wheat flour with non-wheat flour leads to ash and dietary fiber enhancement in the wheat based products. In this study, crude fiber contents of the treated biscuits were generally enhanced more in biscuits with defatted MSM, the range obtained was $2.19 \%$ (wheat biscuits) and $6.52 \%$ in WSD, $5.44 \%$ in WYD, the least $2.82 \%$ was observed in WCD for inexplicable reason. The variations in 
the crude fiber contents of the treated biscuits could be traced to differences in the composition of the different tubers coupled with the enhancing effect of defatting on the crude fiber contents of the MSM. The variations in the ash contents (1.61-3.29\%) could only result from tuber flours and defatting process. Generally, the ash contents were greater in the biscuits with full fat MSM. The least was observed in the wheat biscuits $(1.61 \%)$ and higher values in WCF (3.29\%), WYF (3.11\%), and WSD (3.06\%) was an exception because it did not contain fullfat MSM. Reported values for ash and crude fiber in the literature vary due to differences in blending ratios of constituent ingredients, their processing regimen, as well as differences in the composition of the non-wheat flours used for formulation among other factors. For wheat-sorghum biscuits, Adebowale et al. [37] reported ash and fiber contents that were generally less than $2 \%$, perhaps due to lower flour extraction. Biscuits containing defatted MSM had enhanced carbohydrate contents (75-76\%). A smaller carbohydrate contents (48.74-55.96\%) was reported by Agu and Okoli [31] for beniseed treated biscuits probably due to higher fat content (30.07-35.81\%) reflecting the high fat content in the formulation devoid of starchy root flour. Defatting enhanced the cabonhydrate contents of the biscuits with defatted MSM. The calorific values of the biscuits reflected their fat and carbohydrate contents and calorific values varied from $389.87 \mathrm{Kcal}$ to $437 \mathrm{Kcal} / 100 \mathrm{~g}$; closer to a range of 440.21 to $465.75 \mathrm{kcal} / 100 \mathrm{~g}$ reported by Hossain et al. (38) for various biscuits from Bangladesh containing different levels of fats and carbohydrates, the two ingredients responsible for energy values of biscuits, therefore Agu and Okoli (31) reported greater calorific values $(526.53-554.24 \mathrm{kcal} / 100 \mathrm{~g})$ because their formulations contained $50 \%$ fat against $30 \%$ used in this study. The lower calorific values of the biscuits containing defatted MSM revealed the importance of fat to the overall energy values of food products however, nutrition conscious modern man is weary of consuming high amount of fat especially saturated ones and such biscuits have higher tendency for lipid oxidation during storage and the subsequent deterioration in the nutritive value and sensory properties.

Table 5. Proximate composition (\%) of the various biscuits produced from the flour blends (wheat-tuber- melon seed) flours

\begin{tabular}{|c|c|c|c|c|c|c|c|}
\hline Formulations & Moisture & Protein & Ash & Crude Fat & $\begin{array}{c}\text { Crude } \\
\text { Fiber }\end{array}$ & $\begin{array}{c}\text { Carbo } \\
\text { hydrate }\end{array}$ & $\begin{array}{c}\text { Colorie } \\
\text { (kcal) }\end{array}$ \\
\hline W100:00 & $4.40^{\mathrm{ab}}$ & $6.12^{\mathrm{cd}}$ & $1.61^{\mathrm{c}}$ & $12.69^{\mathrm{ab}}$ & $2.19^{\mathrm{b}}$ & $72.88^{\mathrm{ab}}$ & $430.21^{\mathrm{ab}}$ \\
\hline WCF & $3.84^{\mathrm{b}}$ & $7.96^{\mathrm{b}}$ & $2.98^{\mathrm{a}}$ & $15.00^{\mathrm{ab}}$ & $4.49^{\mathrm{ab}}$ & $65.71^{\mathrm{c}}$ & $429.68^{\mathrm{ab}}$ \\
\hline WCD & $4.11^{\mathrm{ab}}$ & $7.77^{\mathrm{b}}$ & $1.67^{\mathrm{c}}$ & $7.80^{\mathrm{de}}$ & $2.90^{\mathrm{bc}}$ & $75.80^{\mathrm{a}}$ & $404.28^{\mathrm{c}}$ \\
\hline WIF & $4.70^{\mathrm{a}}$ & $8.05^{\mathrm{ab}}$ & $1.49^{\mathrm{cd}}$ & $12.22^{\mathrm{bc}}$ & $4.33^{\mathrm{b}}$ & $69.21^{\mathrm{b}}$ & $419.02^{\mathrm{b}}$ \\
\hline WID & $4.55^{\mathrm{ab}}$ & $7.09^{\mathrm{b}}$ & $1.96^{\mathrm{b}}$ & $6.59^{\mathrm{de}}$ & $4.36^{\mathrm{b}}$ & $75.55^{\mathrm{a}}$ & $389.87^{\mathrm{d}}$ \\
\hline WYD & $4.29^{\mathrm{ab}}$ & $6.82^{\mathrm{c}}$ & $2.91^{\mathrm{a}}$ & $10.25^{\mathrm{e}}$ & $4.58^{\mathrm{ab}}$ & $71.15^{\mathrm{ab}}$ & $404.13^{\mathrm{c}}$ \\
\hline WYD & $4.41^{\mathrm{ab}}$ & $6.98^{\mathrm{c}}$ & $1.82^{\mathrm{b}}$ & $5.27^{\mathrm{e}}$ & $5.47^{\mathrm{ab}}$ & $76.11^{\mathrm{a}}$ & $379.79^{\mathrm{f}}$ \\
\hline WSF & $4.35^{\mathrm{ab}}$ & $8.74^{\mathrm{a}}$ & $2.81^{\mathrm{a}}$ & $16.88^{\mathrm{bc}}$ & $4.41^{\mathrm{b}}$ & $62.76^{\mathrm{d}}$ & $437.92^{\mathrm{c}}$ \\
\hline WSD & $4.80^{\mathrm{ab}}$ & $8.66^{\mathrm{a}}$ & $2.45^{\mathrm{ab}}$ & $11.39^{\mathrm{a}}$ & $6.52^{\mathrm{bc}}$ & $66.20^{\mathrm{c}}$ & $401.95^{\mathrm{c}}$ \\
\hline
\end{tabular}

Results reported as mean of triplicate determinations, means within a column with similar superscripts are significantly not different ( $p>0.05)$. W=wheat (65\%), $C=$ cassava (25\%), $I=I r i s h$ potato $(25 \%), \quad S=$ sweet potato (25\%), Y=Yam (25\%), F=Full fat melon seed meal (10\%), D=Defatted melon seed meal (10\%). All blended in the same ratio of $65: 25: 10$ 
Physical dimensions, strength and spread ratio of the various wheat-tuber-melon seed meal biscuits Diameter of the control was smaller $(5.0 \mathrm{~cm})$ same as WSD $(5.0 \mathrm{~cm})$, the treated were slightly greater and ranged from $5.0-5.67 \mathrm{~cm}$, opposite trend was observed in the thickness of the biscuits $(0.58 \mathrm{~cm}-.063 \mathrm{~cm})$. Spread ratios (7.9-9.2) of the treated were slightly higher more in biscuits with defatted MSM. For wheat-yam starch-oleifera seed flour biscuits, Okereke et al.[39] reported lower values for diameter $(3.68-4.96 \mathrm{~cm})$ and higher thickness $(0.63-1.01 \mathrm{~cm})$ and lower spread ratios (4.15-6.24) probably due to disimilar biscuit formulation. Das et al.[18] similarly observed decrease in diameter with decreased pumpkin seed flour addition and thickness increased and spread factors decreased but in this study the control had the least spread ratio perhaps due to constant blending ratio. Higher spread ratios in the treated correlates with higher nutrient density.

Total weight before fracture ranged from $527.5 \mathrm{~g}$ (WSD) to 918.6 (control), an equivalent fracture force of $6.53 \mathrm{~N}$ to $10.52 \mathrm{~N}$, the value recorded for the wheat biscuit was not significantly different from those of WIF (10.44N) and WID (10.43N) that contained defatted MSM. Khlunklin and Savage [29] contrarily reported a greater range of 11.6-16.5N hardness for the biscuits produced from blends containing graded levels of green lipped mussel flour while Saini et al. [28] also reported that hardness increased with increased inclusion of potato flour. On the other hand, Adebowale et al. [37] observed a decrease with increased replacement of wheat flour, wheat biscuit being the hardest as observed in this study. Biscuit formulation especially the level of fat is responsible for the differences in biscuit hardness, texture or crispness reported in the literature. Gupta and Prevamalli [40] observed direct relationship between snack crispness and fat content. Incorporation non-wheat flour into wheat flour leads to gluten dilution and consequently to enhanced spread ratio and indirectly to enhanced nutritive value due to enhanced biscuits diameter, increased starch gelatinization which occur during baking. Although gluten content is not a critical factor in biscuit making unlike bread production, still it is needed for structural strength of the final product apart from the viscoelasticity of the dough [14]. Higher dough extensibility due to higher water absorption of composite flours is responsible for the variations in physical dimensions of composite biscuits. Unexpected variation of spread ratio in biscuits manufacturing is a quality control department nightmare because it leads to wastage either due to underfilling or forcing products into preformed packages with biscuits with less than optimal dimensions, which is detrimental to handling and storage process. Product formulation and baking conditions also influence biscuit dimensions, which in turn affect the spread ratio and biscuit strength.

Table 6. Physical dimension, strength and spread ratio of the various wheat-tuber-melon seed meal biscuits

\begin{tabular}{|c|c|c|c|c|c|}
\hline Formulation & $\begin{array}{c}\text { Diameter } \\
(\mathbf{c m})\end{array}$ & $\begin{array}{c}\text { Thickness } \\
(\mathbf{c m})\end{array}$ & $\begin{array}{c}\text { Spread } \\
\text { Ratio }\end{array}$ & $\begin{array}{c}\text { Required force } \\
(\mathbf{N}) \text { for fracture }\end{array}$ & $\begin{array}{c}\text { Equivalent weight before } \\
\text { fracture }\end{array}$ \\
\hline W100:00 & $5.00^{\mathrm{a}}$ & $0.63^{\mathrm{a}}$ & $7.9^{\mathrm{b}}$ & $10.52^{\mathrm{a}}$ & $918.6^{\mathrm{a}}$ \\
\hline WCF & $5.17^{\mathrm{a}}$ & $0.61^{\mathrm{a}}$ & $8.5^{\mathrm{ab}}$ & $8.95^{\mathrm{b}}$ & $852.0^{\mathrm{c}}$ \\
\hline WCD & $5.50^{\mathrm{a}}$ & $0.60^{\mathrm{b}}$ & $9.2^{\mathrm{a}}$ & $7.48^{\mathrm{c}}$ & $637.5^{\mathrm{e}}$ \\
\hline WIF & $5.17^{\mathrm{a}}$ & $0.59^{\mathrm{b}}$ & $8.8^{\mathrm{ab}}$ & $7.14^{\text {cd }}$ & $618.6^{\mathrm{f}}$ \\
\hline WID & $5.58^{\mathrm{a}}$ & $0.58^{\mathrm{b}}$ & $9.6^{\mathrm{a}}$ & $10.44^{\mathrm{a}}$ & $911.8^{\mathrm{a}}$ \\
\hline WYF & $5.33^{\mathrm{a}}$ & $0.62^{\mathrm{a}}$ & $8.6^{\mathrm{ab}}$ & $8.99^{\mathrm{b}}$ & $721.3^{\mathrm{d}}$ \\
\hline
\end{tabular}




\begin{tabular}{|c|l|l|l|l|l|}
\hline WYD & $5.67^{\mathrm{a}}$ & $0.62^{\mathrm{a}}$ & $9.2^{\mathrm{a}}$ & $10.43^{\mathrm{a}}$ & $890.9^{\mathrm{b}}$ \\
\hline WSF & $5.40^{\mathrm{a}}$ & $0.59^{\mathrm{b}}$ & $9.2^{\mathrm{a}}$ & $7.13^{\text {cd }}$ & $531.0^{\mathrm{g}}$ \\
\hline WSD & $5.00^{\mathrm{a}}$ & $0.62^{\mathrm{a}}$ & $8.1^{\mathrm{b}}$ & $5.63^{\mathrm{d}}$ & $527.5^{\mathrm{g}}$ \\
\hline
\end{tabular}

Results reported as mean of triplicate determinations, means within a column with similar superscripts are significantly not different ( $p>0.05)$. W=Wheat (65\%), C=Cassava (25\%), $I=I$ rish potato $(25 \%), S=$ sweet potato (25\%), Y=Yam (25\%), F=Full fat melon seed meal (10\%), D=Defatted melon seed meal (10\%). All blended in the same ratio of 65:25:10

\section{Sensory properties of the various blends}

Biscuit colour is determined by the extent of Maillard reaction during baking, a function of the availability of simple sugars and nitrogenous substrates in the formulations. Wheat biscuit had the highest score (8.40) not significantly $(\mathrm{p}<0.05)$ different from WSD biscuit $(8.35)$. There were no significant variation in the colour scores of cassava, yam and sweet potato containing biscuits treated with either full fat or defatted MSM but Irish potato biscuits had the least scores (6.20-6.25), perhaps due to pronounced enzymatic browning that was not effectively checked by hot water blanching of the sliced pieces. The slight decrease in the colour scores of the treated biscuits could be linked to partial substitution of wheat flour with non-wheat flours in the formulations, however the colour scores were appreciably high. Similar to Dadson et al. [34] wheat-yam biscuits (70:30), the colour of wheat biscuit was better but other sensory attributes evaluated were comparable.

The taste and aroma of the various biscuits as represented by favour varied from 5.75 to 7.95 , the flavour of baked wheat-based products is unmistakably appealing and for centuries it has indelibly stamped on consumers psyche that even a better aroma or taste originating from novel products are ignored. However, wheat and full fat treated sweet potato biscuits had equivalent favour scores 7.95 and 7.68 respectively. Others except WYD (5.85) and WSD (5.75) had flavour scores above 6 on a 9 point Hedonic scale. Expectedly, the flavour of biscuits with full fat MSM were adjudged better than biscuits with defatted MSM.

Biscuits are generally known for their high fat and sugar contents which are responsible for their alluring taste. As for taste scores (5.66-8.37), wheat biscuits outscored (8.37) the treated biscuits. Variations in the taste scores of the biscuits with full fat or defatted MSM did not follow a definite pattern, however among the treated, wheat-sweet potato-MSM fullfat (WSF) had better taste perhaps due to the natural sweetness of sweet potato and its counterpart WSD the least because sugars are soluble in aqueous ethanol used for defatting process. The accepted fact is that fats are flavour retainers and tenderizers. Most biscuits are not mealy but crispy, a term that represents dry, tenderly hard piece, that easily breaks with inviting noise when masticated.

Although, wheat biscuits had the highest crispness score but not significantly different from the crispness scores of some of the treated biscuits, but biscuits with full fat MSM had greater crispness scores unexpectedly than those with defatted MSM. Again Irish potato containing biscuits had lower crispness scores perhaps due to greater number of coarse flour particles as revealed in Table, that disallowed the formation of a homogenous crispy hard mass, therefore softer texture. But Chandra et al. [7] reported an increase in texture scores with increased 
replacement of wheat flour contrary to the observation here. The various biscuits were generally accepted, acceptability scores ranged from 6.35 to 8.40 (W100:00), none was rejected and with the exception Irish potato containing biscuits, all other treated biscuits competed favorably with wheat biscuit especially sweet potato containing biscuits.

Table 7. Scores of sensory attributes of the various blends

\begin{tabular}{|c|c|c|c|c|c|}
\hline Formulation & Colour & Flavor & Taste & Crispness & Overall acceptability \\
\hline W100:00 & $8.42^{\mathrm{a}}$ & $7.95^{\mathrm{a}}$ & $8.37^{\mathrm{a}}$ & $8.00^{\mathrm{a}}$ & $8.40^{\mathrm{a}}$ \\
\hline WCF & $7.50^{\mathrm{b}}$ & $6.45^{\mathrm{c}}$ & $6.58^{\mathrm{cde}}$ & $6.86^{\mathrm{c}}$ & $7.76^{\mathrm{b}}$ \\
\hline WCD & $7.50^{\mathrm{b}}$ & $6.06^{\mathrm{cd}}$ & $6.80^{\mathrm{bcd}}$ & $7.11^{\mathrm{bc}}$ & $7.64^{\mathrm{b}}$ \\
\hline WIF & $6.20^{\mathrm{c}}$ & $6.35^{\mathrm{c}}$ & $7.00^{\mathrm{bcd}}$ & $6.22^{\mathrm{cd}}$ & $6.50^{\mathrm{c}}$ \\
\hline WID & $6.25^{\mathrm{c}}$ & $6.24^{\mathrm{cd}}$ & $6.30^{\mathrm{b}}$ & $5.77^{\mathrm{e}}$ & $6.35^{\mathrm{c}}$ \\
\hline WYF & $7.75^{\mathrm{b}}$ & $5.86^{\mathrm{de}}$ & $6.68^{\text {cde }}$ & $7.40^{\mathrm{b}}$ & $7.55^{\mathrm{b}}$ \\
\hline WYD & $7.70^{\mathrm{b}}$ & $6.05^{\mathrm{cd}}$ & $7.29^{\mathrm{bcd}}$ & $7.10^{\mathrm{bc}}$ & $7.65^{\mathrm{b}}$ \\
\hline WSF & $7.55^{\mathrm{b}}$ & $7.68^{\mathrm{a}}$ & $7.30^{\mathrm{bc}}$ & $7.55^{\mathrm{b}}$ & $7.70^{\mathrm{b}}$ \\
\hline WSD & $8.35^{\mathrm{a}}$ & $5.75^{\mathrm{de}}$ & $5.65^{\mathrm{bc}}$ & $6.22^{\mathrm{cd}}$ & $6.88^{\mathrm{b}}$ \\
\hline
\end{tabular}

Results reported as mean of triplicate determinations, means within a column with similar superscripts are significantly not different ( $p>0.05)$. W=Wheat (65\%), C=Cassava (25\%), $I=I$ Irish potato (25\%), $S=$ sweet potato (25\%), Y=Yam (25\%), F=Full fat melon seed meal (10\%), D=Defatted melon seed meal (10\%). All blended in the same ratio of 65:25:10

\section{Summary and Conclusion}

Wheat and cassava flours had the least retentions on $<0.25 \mathrm{~mm}$ sieves a sign of finer granulation. Contrarily, sweet potato, yam and Irish potato flours in increasing order had bigger flour particles or coarse granulation, the implications were manifested in the sensory and hydration properties of the various flour blends and biscuits.

The dry matter comprising of ash, crude fibre, crude fat of the melon seed meal (MSM) fortified blends were enhanced but the crude protein content of the wheat flour was still higher due to diluting influence of root/stem tuber flours $(25 \%)$ in the blends. Moisture contents of the various biscuits were very low, but the protein, ash, fat, and fibre of the MSM treated biscuits were higher than in wheat biscuit, however the observed mean values obtained for the biscuits were less than the values recorded for the blends except crude fat. Calorific values were greater in $10 \%$ fullfat MSM biscuits, however none exceeded 450kcal/100g. Biscuits diameter, thickness and spread ratio (SR) did not vary much, however biscuits with 10\% fullfat MSM had slightly higher SR. Wheat biscuit required greater weight or force before fracture than the treated therefore was harder. With the exception of wheat-Irish potato-MSM biscuits, the sensory scores of all other treated biscuits were comparable with that of 
Asian Journal of Applied Science and Technology (AJAST)

Volume 5, Issue 3, Pages 196-212, July-September 2021

wheat biscuit, however the later outscored in all the attributes tested. The study therefore, successfully produced acceptable and nutritionally enriched biscuits from flour blends of wheat-tuber-MSM without undermining physical and sensory properties associated with biscuits.

\section{Declarations}

\section{Source of Funding}

This research did not receive any grant from funding agencies in the public, commercial, or not-for-profit sectors.

\section{Competing Interests Statement}

The authors declare no competing financial, professional and personal interests.

\section{Consent for publication}

Authors declare that they consented for the publication of this research work.

\section{Data Availability}

Authors are willing to share the data and materials based on relevant needs.

\section{References}

[1] M.A.K Ogunjobi and S.O Ogunmola 2018. Physiochemical and sensory properties of cassava flour biscuit supplemented with cashew apple powder. J. of Food Technology. Vol. 18. pp 24-29. Doi. 10.3923/jftech. 2010.24.29.

[2] M.A.Kerr, K.L Rennie, T.A McCaffrey, J.M Wallace, M.Hannon Fetcher, M.B Livingstone. Snacking pattern among adolescents; a comparison of type frequency and portion size between Britain's 1997 and Northern Ireland 2005. British Journal of Nutrition. 33(5): 208/212 2003.

[3] Akoja J.S and Coker O.J. Functional properties, nutritional and sensory qualities of wheat biscuit fortified with defatted dioclea reflex seed flour. J. of Environmental Science, Toxicology and Food Technology. IOSR vol. 13. Issue II serial 1(Nov 2019); pp 46-55.

[4] Ranjana S, Mohomoodally F. M, Ramasawmy D, Is healthy eating behavior common among school adolescent in Mauritius? Curr. Res. in Nutr. Food Sci., 2013 1(1): 11-22, doi :http://dx. doi.org/10.1294/CRNFST.1.1.02.

[5] Awika JM, Major cereal grains production and use around the world In: Advances in cereal science: Implications to food processing and health promo (eds: JM Awika, V Pironen, S. Bean) 1089: 1-13, 2001.

[6] Saraswathi D, Renu R, Srinivas Maloo, Development and quality evaluation of pumpkin seed and flax seed powders incorporated biscuits, Int Journal of Food Sci and Nutr, 2018 3(2): 78-83.

[7] Suresh Chandra, Samsher Singh and Durvesh Kumari 2015. Evaluation of functional properties of composite flour and sensorial attributes of composite flour biscuit. J. of Food Science and Technology. (6): 3681-3688 doi:10.1007/393197-014-1427-2. 
Asian Journal of Applied Science and Technology (AJAST)

Volume 5, Issue 3, Pages 196-212, July-September 2021

[8] Edema M.O, L.O Sanni and A.I Sanni 2005. Evaluation of maize- soya beans flour blends for sour maize bread production in Niger. Afr. J. of Biotechnology, 2005 (4): 911-918.

[9] Giami SY, Amasi T, and Ekiyor G (2004) Comparison of bread making properties of composite flour from kernels of roasted and boiled African bread fruit (Treculia africanadecne) seeds. J. Raw Material Res.1: 16-25.

[10] Gina K, Elise F. Talsma (2019) Sustainable Food System and Agriculture In: Encyclopedia of Food Security and Sustenablity.

[11] Index Box (2021) World cassava market overview 2021. Available from https://www.indexbox.io/store/ world-cassava-market. Accessed:12 $2^{\text {th }}$ August 2021.

[12] FAO, Storage and processing of root and tubers in the tropics. fao corporate document repository (ed DJB Calverley) 1998; FAO, Rome.

[13] Chandrasekhar A and Kumar TJ (2016) Roots and tuber crops a functional foods: A review on phtytochemical constituents and their potential health benefits. Int. J. Food Science, volume 2016, Article ID3631647, 5pp. http://dx. doi. org/10.1155/2016/3631647.

[14] Weiser, H (2007) Chemistry of gluten proteins. Food microbiol. 24: 115-119.

[15] Nwankwo CM, Nwakodo CS, ndulaka JC, and Nwokocha NJ (2018) Production and proximate composition of ogiri-ahuekere (Arahis hypogaea Linn) Seed condiment. Res. J. Agric and Environmental Mgt, Vol. 7(1): 007-017.

[16] S.Gurudeeban, K. Satyavani and T. Ramanatha (2010). Bitter apple (citrullus colocyrithis): An overview of chemical composition and Biomedical potentials. Asian J.of Plant Sciences, vol 9(7): 394-401 Doi: 10.3923/ajps.2010 394.401.

[17] ENT Akobundu, JP Cherry, JG Simmons Mary (1982). Chemical, functional, and nutrional properties of Egusi (Colocynthis citrullus L.) seed protein products. J. Food Science Vol 47 issue 3, https://doi.org/j.13652621.1982.tb1275.x.

[18] Das S, Ghosh M and Chakraborty P (2021) Study of the utilization of pumpkin seeds for the production of nutritionally enhanced biscuits. Int J. Food and Nutrition vol 6(4): 63-67.

[19] D.Saraswati, R Renu Srinvas Maloo. Determination and quality evaluation of pumpkin seeds and flax seed powder incoporated biscuits. Intl. J. of Food Science and Nutrition. Vol 3issue 2 March 2018 78-83.

[20] AACC (2000) Approved methods of the association of chattered chemists, 10th ed., AACC In. St Paul, Minn.

[21] Ohaka J. C. and Isiehi M. I. Development and quality evaluation of cowpea wheat biscuits. Nigeria Food Journal; 1990, 8: 56-62.

[22] O O, Oladunmoye, R Akinoso, and AA Olapade. Evaluation of some physiochemical properties of wheat, cassava, maize and cowpea flours for bread making. Journal of Food Quality 33 (2010): 693-708. DOI: 10.1111/j.1745-4557.2010.00351.x. 
Asian Journal of Applied Science and Technology (AJAST)

Volume 5, Issue 3, Pages 196-212, July-September 2021

[23] M Marchini, E Carini, N Cataldi, F Boukid, M Blandino, T Ganino, E Vittadini, N Pellegrini (2020) The use of red lentils flour in bakery products: How do particle size and substitution level affect theological properties of wheat bread dough? LWT-Food Science and Technology, DOI: 10.1016/j.lwt.2020 110299.

[24] Bourre L, Frohlich P, Young G, Borsuk Y, Sopiwnyk E, Darker, A and Malcolmson L, Influence of particle size on flour and properties of yellow pea, navybean and red lentil flours, Cereal Chem 96(4): 655-667, https://doi. org/10.1002/cche.1016.

[25] Belorio M, Sahagun M, Gomez M (2019) Influence of flour particle size distribution on the quality of maize gluten free cookies. Foods, 8(2):83 DOI:10.3390/foods8020083.

[26] Mohammed 1, Abdulrahman, A and Senge B. Dough rheology and bread quality of wheat -chickpea flour blends. Industrial Crops and Products; 2012 36(1): 196-202. DOI: 10.1016/jindcrop.2011.09.006.

[27] Nneoma Elechi Obasi, Ngozi Uchechukwu, Enyidiya Eke-Obia. (2012) Production and Evaluation of biscuits from AYB (Sphenostlin Sternocarpa) and wheat (Triticum aestivum) flours. Food Science and Quality Management, Vol. 72012.

[28] P Saini, N Yadav, D Lauren, VK Gupta, B Kaundal, P Misheard, A Misheard and R Kumar (2017) Physicochemical, functional and biscuit making properties of wheat flour and potato flour blends Curr. Nutr. and Food Science vol 13(3), Doi: 10.2174/15734031/366617022115003.

[29] Warinporn khlunklin and Geoffrey Savage (2017). Physicochemical properties and sensory evaluation of wheat - purple rice biscuit enriched with green-lipped mossel powder (Perna Canaliculus) and spices. J. of Food Quality. Vol. 2018, article ID 7697903, 9pp https://doi.org/10.1155/2018/7697903.

[30] Ravi Kumar, Samsher Singh, Suresh Chandra (2016) studies on proximate analysis of biscuit using multigrain flours during ambient conditions of storage. Intl. J. of Food Science and Nutrition. Vol 1(2) march 2016 39-41.

[31] Helen Obioma Agu and Ndidiamaka Azuka Okoli (2014). Physiochemical sensory and microbial assessment of wheat-base biscuit improved with beniseed and unripe plantain. Food science and Nutrition, 2(5) 4642469.

[32] Okoye J.I and Obi CD 2017. Nutrient composition and sensory properties of wheat-African breadfruit composite flour cookies. Sky Journal of Food Science. Vol.6(3) pp 027-032 http://www.skyjournals.org/SJ7S.

[33] Lazos S. Evangelist (1986). Nutritional, fatty acids and oil characteristics of pumpkin and melon seeds. J. Food Science, Vol. 51, issue 5, https://doi.org/10.1111/j.1365-2621.1986.tb 13133.x.

[34] Georgina Dadson, Nanice Fosu and Herberta Prebie. Quality characteristics of biscuits production from a blend of white yam (D. Rotundata) and wheat (T. Control). Int. Ac. J. of Nutr. and Food Sci.; 2021 Vol 2(2): 1-7.

[35] Apoteola Z. O., Fashakin J. F. Evaluation of cookies from wheat flour, soybeans flour and cocoyam flour blends, 2013; Food Sci and Quality Management, Vol.14 (2013).

[36] Adelakun Oluyemisi Elizabeth and Lawal Monsurat Abiodun. Evaluation of wheat-cassava and soymalt composite flour influenced on biscuits. Pak. J. Food Science, 27(1) 2017: 53-60. 


\section{AJAST}

Asian Journal of Applied Science and Technology (AJAST)

Volume 5, Issue 3, Pages 196-212, July-September 2021

[37] A.A Adebowale, M.T Adegoke, S.A Sanni, M.O Adegunwa and G.O Fetuga. Functional properties and biscuit making potentials of sorghum-wheat in flower composites. Am. J. of food technology, Vol. 7(6); 372-379, 2012.

[38] Md Anwar Hossain, Ashish Kumar Sarker and Sahana Parveen, J Pharm Biol Sci 2013, 1(2): 16-20.

[39] Okereke GO, Igbabul B D, Okay J and Kanu N. A. Int. J. Food Science and Nutr., 2012 vol 6 iss 4, pp.39-50.

[40] Gupta P and Premavalli K.S. Development of radish fibre based snack by response surface methodology. J Food Sci Technol; 2012 49(1): 58-65, DOI: 10.1007/s13197-011-026-z.

[41] Gadzama U S and Agbara G .I. Physical functional properties of flour blends and Dakere (A Nigerian steamed agglomerated dumpling) as affected by flour fractionation and grain legume fortification. International Journal of Advance Science and Research; 2021 Vol. 6(2): 12-17. 